\title{
LGALS8 wt Allele
}

National Cancer Institute

\section{Source}

National Cancer Institute. LGALS8 wt Allele. NCI Thesaurus. Code C51264.

Human LGALS8 wild-type allele is located within 1q42-q43 and is approximately $31 \mathrm{~kb}$ in length. This allele, which encodes galectin- 8 protein, plays a role is several diverse processes that hinge upon integ rin-like cellular interactions such as development, differentiation, cell-cell adhesion, cell-matrix interaction, growth regulation, apoptosis and RNA splicing. 